\title{
Studies on Genetic Variability for Yield and Yield Contributing Traits in Finger Millet Eleusine coracana (L.) Gaertn
}

\author{
B. R. Chavan ${ }^{1 *}$, L. N. Jawale ${ }^{2}$, T. A. Chavan $^{3}$ and A. V. Shinde ${ }^{1}$ \\ ${ }^{1}$ Department of Agricultural Botany, College of Agriculture, Parbhani, \\ VNMKV. Parbhani - 431402 (M.S.) India \\ ${ }^{2}$ Sorghum Breeder, Sorghum Research Station, India \\ ${ }^{3}$ College of Agriculture, Latur, India \\ *Corresponding author
}

\section{A B S T R A C T}

\section{Keywords}

Finger millet, Genetic variability,

Heritability,

Genetic advance.

Article Info

Accepted:

22 August 2019

Available Online:

10 September 2019
Fifteen genotypes of finger millet were evaluated in a field study to assess the magnitude of genetic variability, heritability and genetic advance for yield and yield contributing traits. The analysis of variance revealed that there were significant differences among the entries for all the traits studied. A wide range of variation was recorded for plant height $(\mathrm{cm})$, days $50 \%$ flowering, days to maturity, number of tillers per plant, number of fingers per year, length of finger $(\mathrm{cm})$, test weight $(\mathrm{g})$, yield per plant $(\mathrm{g})$, straw yield per plant $(\mathrm{g})$. The phenotypic coefficient of variation was greater than genotypic coefficient of variation for all the characters studied which shows the influence of the environmental effect on the characters. High values for phenotypic coefficient and genotypic coefficient was recorded for yield per plant (g). High heritability and high genetic advance was recorded for iron content $(\mathrm{mg} / 100 \mathrm{~g})$, yield per plant $(\mathrm{g})$, calcium content $(\mathrm{mg} / 100 \mathrm{~g})$ and test weight $(\mathrm{g})$ indicating that these characters were controlled by additive gene effects. Selection based on these characters would be effective for future finger millet crop improvement program. Moderate heritability coupled with moderate genetic advance was observed for length of finger $(\mathrm{cm})$ and protein content $(\%)$. Plant height $(\mathrm{cm})$ showed low heritability as well as low genetic advance.

\section{Introduction}

Finger millet (Eleusine coracana L. Gaertn., $2 \mathrm{n}=4 \mathrm{x}=36$ ) belongs to the family Poaceae. Among millets it ranks third in importance after sorghum and pearl millets. Its wide adaptability to diverse environments and cultural conditions makes it a potential food crop. It also contains sufficient amount of iron and rich source of calcium. Small millets comprise of Finger millet, Little millet, Foxtail millet, Kodo millet, Barnyard millet and Proso millet is an important group of dry land field crops. Finger millet occupies first place with 
fifty percent of the area. Recently government of India declared millets as a 'Nutricereal' crops being a rich source of minerals in almost all types of millets. The availability of diverse genetic resources is a prerequisite for genetic improvement of any crop including finger millet. The basic information on the existence of genetic variability and diversity in a population and the relationship between different traits is essential for any successful plant breeding programme. Considering its importance in food and fodder security, adequate information on genetic variability between yield and its attributes is meager in finger millet. Systematic breeding efforts in this crop have so far been neglected. For starting any crop improvement work, information about the genetic variability available in the population is a prerequisite. Presence of high variability in the genotypes of this crop offers much scope for its improvement (Poehlman, 1987). Estimation of genetic parameters in the context of trait characterization is an essential component in developing high yielding varieties. Hence, an attempt was made to estimate the extent of variation for yield contributing traits in fifteen finger millet genotypes by studying the genetic parameters like phenotypic coefficient of variation (PCV), genotypic coefficient of variation (GCV), heritability and genetic advance, which may contribute to formulation of suitable selection indices for improvement in this crop.

\section{Materials and Methods}

The field experiment was conducted on the field of Department of Agricultural Botany, College of Agriculture, VNMKV, Parbhani by taking three replications in Randomized Block Design during Kharif, 2017. Experimental material comprises of 13 different genotypes with 2 checks from different diverse sources of country. The materials was grown in randomize block design with three replications
$30 \mathrm{~cm}$ spacing was kept between the rows while, $10 \mathrm{~cm}$ spacing was kept between the plants. The gross plot size was $2 \mathrm{~m} \times 2 \mathrm{~m}$ and net plot size maintained was $1.50 \times 1.60 \mathrm{~m}$. All the agronomic practices were performed for better performance of the trial. The data was recorded in five random plants per entry in each replication viz., plant height $(\mathrm{cm})$, days $50 \%$ flowering, days to maturity, number of tillers per plant, number of fingers per year, length of finger $(\mathrm{cm})$, test weight $(\mathrm{g})$, grain yield per plant $(\mathrm{g})$, straw yield per plant $(\mathrm{g})$, Protein content (\%), Calcium content $(\mathrm{mg} / 100 \mathrm{~g})$ and Iron content $(\mathrm{mg} / 100 \mathrm{~g})$. The mean of all the plants for each trait under each replication was subjected to analysis (Panse and Sukhathme, 1967). The estimate of genotypic variance and phenotypic variance were worked out according to the method suggested by Johnson et al., (1955) using mean square values from the ANOVA table. Phenotypic and genotypic coefficient of variance was calculated based on the method advocated by Burton et al., (1952). Heritability percentage in broad sense was estimated as per the method described by Lush (1940) and traits were classified as having high, moderate and low heritability as per the method of Robinson et al., (1949). Genetic advance was estimated according to the method suggested by Johnson et al., (1955), and expressed as percentage of mean. Traits were classified as having high, moderate or low genetic advance as per the method suggested by Johnson et al., (1955).

\section{Results and Discussion}

In the present investigation, the genetic variability of a metric trait can be studied through the use of various statistical parameters like mean, range, variance components and coefficients of variation. Genetic variability studies provide basic information regarding the genetic properties of the population based on which breeding 
methods are formulated for further improvement of the crop. These studies are also helpful to know about the nature and extent of variability that can be attributed to different causes, sensitivity of crop to environment, heritability of the character and genetic advance. The analysis of variance showed a wide range of variation and significant differences for all the characters under study, indicating the presence of adequate variability for further improvement.

The analysis of variance revealed that the differences among the genotypes were significant for most of the characters under study. The genotypes were thus suitable for genetical studies, as their contribution to the genotypic sum of squares was significant for most of the characters.

The total variability in each of these characters could be partitioned into three components viz., phenotypic, genotypic and environmental. The phenotypic variance and genotypic variance was maximum for calcium content (mg/100g) and days to maturity. Genotypic and phenotypic variances were high for calcium content $(\mathrm{mg} / 100 \mathrm{~g})$, followed by days to maturity, days $50 \%$ flowering plant height and harvest index (\%), straw yield per plant indicating wide variability for these characters.

A wide range of variation was recorded for days to $50 \%$ flowering, plant height, days to maturity, straw yield per plant, calcium content $(\mathrm{mg} / 100 \mathrm{~g})$, iron content $(\mathrm{mg} / 100 \mathrm{~g})$ and harvest index (\%). The estimates of phenotypic coefficient of variation ranged from 8.172 for Plant height $(\mathrm{cm})$ to 24.690 for Iron content $(\mathrm{mg} / 100 \mathrm{~g})$ and the corresponding values for genotypic coefficient of variation were 7.300 for Plant height $(\mathrm{cm})$ to 0.890 for Iron content $(\mathrm{mg} / 100 \mathrm{~g})$, respectively. Yield per plant (g) showed nearly high PCV and GCV values. Similarly, high genotypic and phenotypic coefficient of variation was also found Yield per plant (g) by Abraham et al., (1989). No. of fingers per year, Days 50\% flowering and Straw yield per plant (g) showed moderate phenotypic coefficient of variation and genotypic coefficient of variation. In general, the differences between phenotypic coefficient of variation and genotypic coefficient of variations for most of traits were less indicating the ample scope for improvement through selection. Low values of phenotypic coefficient of variation and genotypic coefficient of variation were observed for plant height and No. of fingers per ear indicating narrow range of variability for these traits there by restricting the scope for selection.

Heritability which is the heritable portion of phenotypic variance is a good index of transmission of characters from parents to offspring (Falconer, 1981). The heritability values for different yield and yield attributing traits ranged from $59.6 \%$ to $91.6 \%$. In the present investigation the traits yield per plant $(\mathrm{g})$, iron content $(\mathrm{mg} / 100 \mathrm{~g})$, length of finger (cm), days to $50 \%$ flowering, days to maturity and calcium content $(\mathrm{mg} / 100 \mathrm{~g})$ traits showed high heritability. Moderate heritability was noted in trait plant height, test weight $(\mathrm{g})$ and protein content (\%). The heritability estimates low for No. of tillers per plant, No. of fingers per ear and Harvest index (\%). High heritability indicates the amenability of the traits in the selection process. Likewise, high heritability estimates for days to flowering and maturity (Dhagate et al., 1972) and length of finger $(\mathrm{cm})$ (Daba, 2000). In present study, the values of genetic advance as percent of mean ranged from 0.577 to 123.750 . Calcium content $(\mathrm{mg} / 100 \mathrm{~g})$ recorded highest genetic advance as percent of mean (123.750). High heritability coupled with high genetic advance as per cent of mean was registered for Calcium content $(\mathrm{mg} / 100 \mathrm{~g})$, days to maturity and days to $50 \%$ flowering. 
Table.1 Analysis of variance for yield and yield contributing characters in finger millet

\begin{tabular}{|l|l|c|c|c|}
\hline \multirow{2}{*}{$\begin{array}{l}\text { No } \\
\text { No }\end{array}$} & Characters & \multicolumn{3}{|c|}{ Mean sum of Squares } \\
\cline { 3 - 5 } & & Replication & Treatment & Error \\
\hline $\mathbf{1}$ & Plant height (cm) & 1.870 & 197.369 & 15.358 \\
\hline $\mathbf{3}$ & Days 50\% flowering & 3.800 & 215.819 & 13.633 \\
\hline $\mathbf{4}$ & Days to maturity & 18.20 & 407.51 & 27.70 \\
\hline $\mathbf{5}$ & No. of tillers per plant & 0.179 & 0.484 & 0.089 \\
\hline $\mathbf{6}$ & Length of finger per ear $(\mathrm{cm})$ & 0.108 & 1.757 & 0.167 \\
\hline $\mathbf{7}$ & Test weight $(\mathrm{g})$ & 0.347 & 4.112 & 0.206 \\
\hline $\mathbf{8}$ & Yield per plant (g) & 0.044 & 1.606 & 0.130 \\
\hline $\mathbf{9}$ & Straw yield per plant $(\mathrm{g})$ & 0.549 & 14.468 & 0.429 \\
\hline $\mathbf{1 0}$ & Harvest index $(\%)$ & 0.979 & 19.258 & 1.587 \\
\hline $\mathbf{1 1}$ & Protein content $(\%)$ & 19.160 & 81.168 & 8.286 \\
\hline $\mathbf{1 2}$ & Calcium content $(\mathrm{mg} / 100 \mathrm{~g})$ & 0.089 & 7.999 & 0.784 \\
\hline $\mathbf{1 3}$ & Iron content $(\mathrm{mg} / 100 \mathrm{~g})$ & 1150.344 & 14206.959 & 978.435 \\
\hline & D.F & 1.585 & 67.536 & 2.666 \\
\hline & & 2 & 14 & 28 \\
\hline
\end{tabular}

Table.2 Components of variation for yield attributing characters in finger millet

\begin{tabular}{|l|l|c|c|c|}
\hline $\begin{array}{l}\text { Sr. } \\
\text { No }\end{array}$ & Characters & Phenotypic variance & Genotypic variance & $\begin{array}{c}\text { Environmental } \\
\text { variance }\end{array}$ \\
\hline $\mathbf{1}$ & Plant height $(\mathrm{cm})$ & 76.029 & 60.670 & 15.360 \\
\hline $\mathbf{2}$ & Days 50\% flowering & 81.029 & 67.395 & 13.633 \\
\hline $\mathbf{3}$ & Days to maturity & 154.305 & 126.605 & 27.700 \\
\hline $\mathbf{4}$ & No. of tillers per plant & 0.221 & 0.132 & 0.089 \\
\hline $\mathbf{5}$ & No. of fingers per ear & 0.697 & 0.530 & 0.167 \\
\hline $\mathbf{6}$ & Length of finger (cm) & 1.508 & 1.302 & 0.206 \\
\hline $\mathbf{7}$ & Test weight (g) & 0.622 & 0.492 & 0.130 \\
\hline $\mathbf{8}$ & Yield per plant (g) & 5.108 & 4.680 & 0.429 \\
\hline $\mathbf{9}$ & Straw yield per plant $(\mathrm{g})$ & 7.477 & 5.890 & 1.587 \\
\hline $\mathbf{1 0}$ & Harvest index $(\%)$ & 32.580 & 24.294 & 0.286 \\
\hline $\mathbf{1 1}$ & Protein content $(\%)$ & 3.189 & 2.405 & 978.433 \\
\hline $\mathbf{1 2}$ & $\begin{array}{l}\text { Calcium } \\
\text { (mg/100g) }\end{array}$ & 5387.941 & 4409.509 & 2.666 \\
\hline $\mathbf{1 3}$ & Iron content (mg/100g) & 24.289 & 21.623 & 0.784 \\
\hline
\end{tabular}


Table.3 Genetic variability parameters for yield and yield attributing traits in finger millet

\begin{tabular}{|c|c|c|c|c|c|c|c|c|}
\hline $\begin{array}{l}\text { Sr. } \\
\text { No }\end{array}$ & Characters & Mean & Range & $\begin{array}{l}\text { PCV } \\
(\%)\end{array}$ & $\begin{array}{l}\text { GCV } \\
(\%)\end{array}$ & $\begin{array}{c}\text { Heritability } \\
(\%)\end{array}$ & $\begin{array}{c}\text { Genetic } \\
\text { Advance }\end{array}$ & $\begin{array}{c}\text { Genetic } \\
\text { Advance } \\
\text { as \% } \\
\text { of mean }\end{array}$ \\
\hline 1 & Plant height $(\mathrm{cm})$ & 106.702 & $122.4-98.73$ & 8.172 & 7.300 & 79.8 & 14.333 & 13.433 \\
\hline 2 & $\begin{array}{ll}\text { Days } & 50 \% \\
\text { flowering } & \end{array}$ & 79.733 & $91-63$ & 11.290 & 10.296 & 83.2 & 15.423 & 19.344 \\
\hline 3 & Days to maturity & 116.466 & $129-96$ & 10.666 & 9.661 & 82.0 & 20.996 & 18.027 \\
\hline 4 & $\begin{array}{l}\text { No. of tillers per } \\
\text { plant }\end{array}$ & 2.253 & $3-1.6$ & 20.854 & 16.104 & 59.6 & 0.577 & 25.618 \\
\hline 5 & $\begin{array}{l}\text { No. of fingers per } \\
\text { ear }\end{array}$ & 7.311 & $9.6-6.2$ & 11.418 & 9.960 & 76.1 & 1.309 & 17.898 \\
\hline 6 & $\begin{array}{l}\text { Length of finger } \\
(\mathrm{cm})\end{array}$ & 6.895 & $9.40-4.40$ & 17.810 & 16.546 & 86.3 & 2.184 & 31.667 \\
\hline 7 & Test weight (g) & 3.464 & $5.36-2.24$ & 22.759 & 20.243 & 79.1 & 1.285 & 37.091 \\
\hline 8 & Yield per plant (g) & 9.896 & $14.91-6.37$ & 22.837 & 21.858 & 91.6 & 4.265 & 43.097 \\
\hline 9 & $\begin{array}{l}\text { Straw yield per } \\
\text { plant }(\mathrm{g})\end{array}$ & 21.810 & $28.487-19.28$ & 12.538 & 11.128 & 78.8 & 4.437 & 20.345 \\
\hline 10 & Harvest index (\%) & 43.203 & $50.51-31.897$ & 13.212 & 11.409 & 74.6 & 8.768 & 20.294 \\
\hline 11 & $\begin{array}{l}\text { Protein content } \\
(\%)\end{array}$ & 9.518 & $12.30-7.58$ & 18.760 & 16.292 & 75.4 & 2.774 & 29.147 \\
\hline 12 & $\begin{array}{l}\text { Calcium content } \\
(\mathrm{mg} / 100 \mathrm{~g})\end{array}$ & 349.793 & $421.63-219.37$ & 20.985 & 18.984 & 81.8 & 123.750 & 35.378 \\
\hline 13 & $\begin{array}{ll}\text { Iron } & \text { content } \\
(\mathrm{mg} / 100 \mathrm{~g}) & \end{array}$ & 19.961 & $27.170-9.623$ & 24.690 & 23.295 & 89.0 & 9.038 & 45.278 \\
\hline
\end{tabular}

Moderate heritability coupled with moderate genetic advance was observed for plant height and Iron content $(\mathrm{mg} / 100 \mathrm{~g})$ indicating the presence of both additive and non additive gene action in the inheritance of this trait. No. of tillers per plant showed low heritability as well as low genetic advance besides narrow range of variability restricting the scope for improvement through selection. Low heritability coupled with low genetic advance for the trait indicated that this trait is controlled by environmental effects and simple selection would be ineffective. Heritability estimates along with genetic advance are normally more helpful in predicting the gain under selection than heritability estimates alone. However, it is not necessary that a character showing high heritability will also exhibit high genetic advance (Johnson et al., 1955). According to Panse (1957), if the heritability is mainly owing to non additive gene effect, the expected genetic advance would be low and if there is additive gene effect, a high genetic advance may be expected. Taking into consideration the amount of variability, heritability and genetic advance as per cent of mean in the present study it may be concluded that selection would be effective in number of fingers per ear head, ear head yield, ear head length, days to $50 \%$ flowering, number of productive tillers per plant and grain yield for 
developing high yielding varieties.

It is concluded that yield is controlled by both GCV and PCV also to use appropriate selection procedure for improvement of the characters in general and yield in particular since high heritability coupled with high genetic advance reveals the presence of lesser environmental influence and prevalence of additive gene action in their expression. High heritability with low genetic advance was indicated the influence of non additive gene action. The heritability provide the information on the magnitude of inheritance of quantitative characters, but it does not indicate the magnitude of genetic gain obtained by selection of best individual from the best population. So, heritability along with genetic advance is more useful for selection than the heritability alone.

\section{References}

Abraham, M. J., A. S. Gupta and B. K. Sarma. 1989. Genetic variability and character association of yield and its components in finger millet (Eleusine coracana $\mathrm{L}$. Gaertn) in acidic soils of Meghalaya. Indian J. Agric. Sci. 59:579-581.

Burton, G. W. 1952. Quantitative inheritance in grass. Proceedings of $6^{\text {th }}$ International Grass land Congress 1: 277-283.

Daba, C. 2000. Variability and Association among Yield and Related Traits in
Finger Millet [Eleusine coracana (L) Gaertn]. M.Sc. thesis, Alemaya University.

Dhagate, N. K., G. L. Patidar., P. S. Shrivastava and R. C. Joshi. 1972. Correlation and genetic variability study in ragi [Eleusine coracana (L.) Gaertn]. JNKVV Res. J. 6:121-124.

Falconer, D. S. 1981. Introduction to Quantitative Genetics. $2^{\text {nd }}$ ed. Longman, London.

Johnson, H. W., H. F. Robinson and R. E. Comstock. 1955. Estimate of genetic and environmental variability in Soybeans. Agron. J. 47: 314- 318.

Lush, J. L. 1940. Intra-sire correlation and regression of offspring on dams as a method of estimating heritability of characters. Proc. Ame. Soc. Anim. Prod. 33: 293-301.

Panse, V. G., and P. V. Sukathme. 1967. Statistical Method for Agricultural Workers. ICAR, New Delhi. pp. 381.

Panse, V. G. 1957. Genetics of quantitative characters in relation to plant breeding. Indian Journal of Genetics 17: 318328.

Poehlman, J. M. 1987. Breeding Field Crops. $3^{\text {rd }}$ ed. AVI Publishing Company, Inc. West Port, CT. Pp. 187-213.

Robinson, H. F., R. E. Comstock and P. H. Harvey.1949. Estimates of heritability and the degree of dominance in Corn (Zea mays). Agron. J. 41:353-359.

\section{How to cite this article:}

Chavan, B. R., L. N. Jawale, T. A. Chavan and Shinde, A. V. 2019. Studies on Genetic Variability for Yield and Yield Contributing Traits in Finger Millet Eleusine coracana (L.) Gaertn. Int.J.Curr.Microbiol.App.Sci. 8(09): 2276-2281.

doi: https://doi.org/10.20546/ijcmas.2019.809.263 